Article

\title{
Geochemical Features of Fallow Land in Ancient Plots in the Chora of Chersonesos
}

\author{
Fedor Lisetskii ${ }^{1, *(\mathbb{D})}$, Eugenia Zelenskaya ${ }^{1}$ (D) and Maria Rodionova ${ }^{2}$ (D) \\ 1 Federal-Regional Center of Aerospace and Surface Monitoring of the Objects and Natural Resources, \\ Belgorod National Research University, 308015 Belgorod, Russia; 706629@bsu.edu.ru \\ 2 Institute of Earth Sciences, Belgorod National Research University, 308015 Belgorod, Russia; \\ zamuraeva@bsu.edu.ru \\ * Correspondence: liset@bsu.edu.ru; Tel.: +07-4722-301370
}

Received: 15 October 2018; Accepted: 6 November 2018; Published: 9 November 2018

check for updates

\begin{abstract}
The ancient city of Chersonesos created an agricultural zone in the 4th and 3rd centuries $\mathrm{BC}$ (under the conditions of climate aridization); this zone was initially used for viticulture and the export of wine, and grain farming later developed at the distant chora (in North-Western (NW) Crimea). The purpose of our work was to verify whether the ampeloecological conditions, especially the geochemical features of the soil and rock, limited viticulture in NW Crimea. Fallow lands in 13 plots in the near and distant chora of Chersonesos were studied using ampelopedology; specifically, we compared agrochemical properties and the concentrations of macro- and trace elements in the renaturation soil horizon and in the parent rock. The main differences between the soils of the two regions were determined by the accumulation of cinnamonic soils of Chersonesos $\mathrm{Si}, \mathrm{K}, \mathrm{Fe}, \mathrm{Al}$, $\mathrm{P}_{2} \mathrm{O}_{5}$; in the distant chora, there are specific elements, including $\mathrm{V}, \mathrm{Pb}, \mathrm{Rb}, \mathrm{Cr}$. The climate and the biogeochemical diversity of soils and rock could be significant factors causing the differences in wine quality in the two regions of western Crimea; these factors are still reflected in modern viticultural practices when using the concept of "terroir". These findings are consistent with the different roles of ancient viticulture in SW (South-Western) and NW (North-Western) Crimea (i.e., export and local consumption, respectively), which have been highlighted by historians.
\end{abstract}

Keywords: biogeochemistry; geochemistry soils; parent rock; trace elements; antique vineyards; post-antique fallow land

\section{Introduction}

The characteristics of the natural conditions of the region (i.e., the landscape, climate, physical, chemical, and biological components of the soil and rock) comprise a vital part of the terroir [1-3]. The modern experience of the ampelo-environmental research in viticulture [4-6] has shown that the accounting plays an important role along with the geomorphologic and microclimatic characteristics of the area, including the soil-ecological characteristics, such as profile thickness, granulometric composition, bulk density, humus and carbonate content, $\mathrm{pH}$, and presence of unfavorable properties (e.g., stoniness). These features are particularly evident in the transformation of the soil in the ancient agricultural fields in arid and semiarid regions [7]. The grape has a very well-developed root system; thus, it is characterized by a high ability to extract nutrients from the root layer of the soil, but at the same time, the plant is rather sensitive to environmental factors. Consequently, under different conditions, the plant may yield different harvests in terms of quantity and quality [8]. Since the quality of wine is affected by almost all soil properties and soil fertility, these factors explain the vital role of ampelopedology, which produces the results of genetic soil studies for viticulture [9] and the establishment of a correspondence among the chemical composition of grape, the geochemistry 
of vineyard soil, and the geolithological features of cultivation zone [10]. According to the concept of "terroir", the soil in which grapes are grown plays a major role in the vine behavior, the grape quality, and the wine sensory characteristics [11,12]. Thus, for example, the method developed in France for characterizing viticultural terroirs uses a field soil model based on the type of parent rock, as well as the depth and the clay richness of the soil, mainly in connection with the weathering level of the parent rock [13]. The role of the contents of trace elements (Co, $\mathrm{Ni}, \mathrm{Mn}, \mathrm{B}, \mathrm{Zn}$, etc.) in the soil is just as important for growing high-quality grapes as is the content of the fundamental mineral elements- $\mathrm{N}, \mathrm{P}, \mathrm{K}, \mathrm{Ca}, \mathrm{S}$, and $\mathrm{Mg}[4,5,14-17]$. However, the impact on the productivity of trace elements and in particular of heavy metals depends largely on the soil environment in specific bioclimatic conditions [18-22]. Furthermore, fine-dispersed minerals (silt and clay) appear to be the most relevant soil parameters controlling soil dynamics in the profile of soils and parent rock [23].

In viticulture, it was noticed long ago that the best wines usually grow in shallow soils where the rocks exit to the surface. Obviously, in this case, the quality of wine depends not on the physical properties of the soil, but on the mineral nutrition that the grape receives from the rocks. According to the opinion of V. Akimtsev [24], the quality of wine depends on the entire complex of natural factors; however, the key factors include rocks that have not been completely destroyed and individual elements that are extracted by the grape roots and are accumulated in the grape juice. These elements are further accumulated in wines and affect the wine characteristics [24], which markedly vary from grapes grown in the same soils that have different parent rocks. In such cases, the absorption of the rare elements contained in the rocks may occur in a more concentrated form.

The Crimea Peninsula has a wide variety of soils, orographic and climate conditions; this includes the sub-Mediterranean variation along the southern Crimean coast, which is a region with a long history of viticulture. Tauric Chersonesos was the biggest center of ancient viticulture and wine production along the northern Black Sea coast, and wine was the main export of this Greek city. The agricultural hinterland of the ancient city of Chersonesos on the Herakleian Peninsula (south-west Crimea), known as the chora of Chersonesos functioned for a long period, starting from the period of the initial establishment of Greek farms (ca. 5th century BC) to the beginning of the 1st century AD. Vitis pollen marks the beginning of viticulture by the Greeks ca. 400 BC [25]. Agro-landscapes of different ages formed during the lifespan of ancient Chersonesos and medieval Cherson.

The climate and its changes within the last several thousand years are very important for the development of viticulture and the formation of biogeochemical properties of soils and rock. The climate in the western part of the Crimean Peninsula is a mild steppe in the plains and transitions to sub-Mediterranean in the southwest.

The study of palaeosoils of barrows belonging to the Eneolithic Age, the Bronze Age and the Middle Age, are located within the modern steppe area, and these studies have shown the rhythmic changes of watering conditions with several periods of aridization [26]. The speed of soil mineral weathering cannot be considered as the single source of cations in the soil, as other sources of cations in soil are related to a higher level (compared to rock weathering) of mineralization of necro-material, including humus [27]. These processes considerably depend on the "soil climate" and its changes over the Late Holocene. The acceleration of all soil processes occurs when there is an increase in humid climates, including slow increases; specifically, argillization, superdispersity of clay minerals, and changes in elemental composition occur [28].

In the northern Black Sea region at the turn of the 4th and 3rd centuries BC, the cool and humid climate abruptly changed into a warm and dry climate. This, according to archaeological data $[29,30]$, led to the development of wineries with large-volume reservoirs, and wineries began to open more frequently in the cities as well as in the villages. During this period, the climate was hot and dry, but it changed into a more humid climate with two dry phases [31] before the farms were abandoned (Byzantine period). From the beginning of the 1st century AD most farms of the chora Chersonesos were abandoned as winemaking declined [32]. Despite this decline, various farms remained active during the Roman and Byzantine periods, apparently focused on gardening [32]. The long-fallowed 
lands have suffered two phases of humid and dry climate [33] that could affect the conservation of the palaeomorphic features of agrogenesis. When croplands are abandoned, the starting conditions for the restoration process largely depend on the site-specific ecological characteristics (i.e., soil type, climate, former crops, field area, and availability of propagules) [34]. However, it can be assumed that the secondary succession (i.e., the recovery of plant communities on regenerating soil) will not fully erase evidence of the ancient agrogenic loads.

New knowledge can be obtained by using existing developments in modern ampelopedology for the purpose of exploring the areas of ancient viticulture. The hypothesis of this work was to determine whether the environmental conditions, especially the properties of soils and rock in North-Western (NW) Crimea, limited the development of viticulture (with export potential in quantity and quality) in the formation of the distant chora of Chersonesos during the 4th and 3rd centuries BC.

The present study aimed to use an interdisciplinary approach that could integrate the methods of Archaeology and Geosciences for the study of ancient perennial plantations (vineyards and gardens).

\section{Materials and Methods}

\subsection{Objects of Soil-Genetic Research}

The field work was carried out in 2012-2014 with the information support of the staff of the National Preserve of Tauric Chersonesos. In addition to the well-known regions of ancient viticulture along the northern Black Sea coast (along the Lower Bug (Olbia), SW Crimea (Chersonesos), Eastern Crimea, and Taman (Bosporus)), much less data exists on the establishment of perennial plantations in rural areas of NW Crimea, which was included in the 4th-beginning of 3rd century BC in the Chersonesos state [30]. If farming in NW Crimea, which had specialized in the cultivation of food grains, was the main branch of the crop, then grapes represented the second largest culture. However, traces of the ancient demarcation of land used for gardening and viticulture have been discovered in eight locations in NW Crimea.

The objects of study in the distant chora of Chersonesos are located in the coastal area (Kalos Limen $(\mathrm{K}-\mathrm{L})$, at Cape Ojrat (OT)), and in the interior area (Ortli (OR), Mamay-Tyup (MT)). An ancient Greek vineyard on the Crimean Peninsula (Ortli, Mamay-Tyup) was first identified from a satellite photograph; however, it was discovered only after using a magnetic survey [30].

An area of specialized viticulture occurred in ancient times near Chersonesos (in the Herakleian Peninsula), where buried vineyards are still available for study. The larger part of the Herakleian Peninsula (about 10 thousand ha) had been simultaneously divided into a system of approximately 500 rectangular plot of land, mainly of similar area (by $26.5 \mathrm{ha}$ ) in the 4th century BC. Two main types of dry forest and bush soils are located here, i.e., cinnamonic light-clayey soils (a sub-Mediterranean variation of the terra rossa) and rendzina soils [25]. Soils are generally thin, stony, and carbonate-rich. The region's climate is very dry and moderately hot, with fairly mild winters with an average annual temperature of $10.3-12.0^{\circ} \mathrm{C}$, the sum of active temperatures $\left(\Sigma \mathrm{t}>10^{\circ}\right)$ per year amounts to $3300-3500^{\circ} \mathrm{C}$ and an annual precipitation of 350-475 $\mathrm{mm}$ [35-37].

From the perspective of ampeloecological assessments of certain regions of Crimea, which differ in soil and climatic conditions and where viticulture played different roles, it was important to compare the fallow soil under ancient vineyards in NW Crimea and in the Herakleian Peninsula (Figure 1). To do this, we compared the previously studied soils [38] of six land plots of Chersonesos (CN 3, 49, 62, 68, 387, and 389) (Figure 1) and chose two with the most contrasting soils: in plot No 3 (near Omega Bay) and CN 387 (near Cape Fiolent). These were the most remote from each other and were located in a delimited part of the Chersonesos rural district; however, they still had very strong differences in the concentration of carbonates in the soils. 

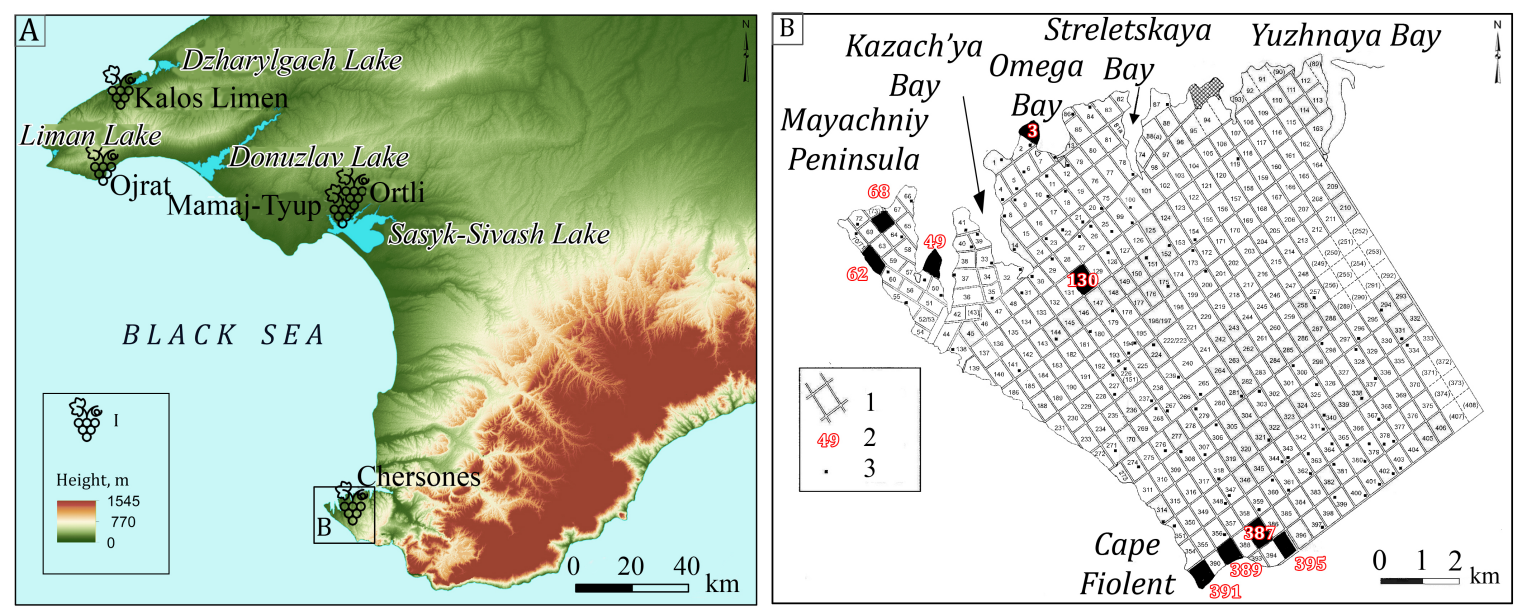

Figure 1. Objects of soil-genetic research in NW Crimea (A) and in plots of Chersonesos (B): 1-Division Lines; 2-Farm Number; 3-Farm Houses (Modified from [25,32]).

\subsection{Experimental Treatments}

Soil sampling on the fallow land was conducted in horizon A in the $0-16 \mathrm{~cm}$ layers. The geochemical characteristics of the parent rock, which was taken from a depth $60-70 \mathrm{~cm}$, were required to calculate the coefficient of the microelement accumulation capability.

The main analytical procedures were performed according to standard methods [39] in the Chemical-Analytical Complex of the Institute of Physical, Chemical and Biological Problems in Soil Science, Russian Academy of Sciences, Pushchino.

Chemical analyses of vineyard soils included the following standard procedures: The Corg content, by Tyurin's method; $\mathrm{CO}_{2}$ in carbonates by acidometry; $\mathrm{pH}\left(\mathrm{H}_{2} \mathrm{O}\right)$ by potentiometric method ( $\mathrm{pH}$ meter Sartorius Basic Meter PB-11); the available $\mathrm{P}_{2} \mathrm{O}_{5}\left(\mathrm{mg} \mathrm{kg}^{-1}\right)$ by Machigin's method (spectrophotometer UNICO-1200, USA, 2012), and $\mathrm{K}_{2} \mathrm{O}$ on a fiery photometer. The determination of cation exchange capacity (CEC) in calcareous soils was performed using EDTA-Na 2 . Concentration of 20 metals and their oxides (9 macroelements and 11 trace elements) within the soils were determined by the technique of measuring the metal's mass fraction and the oxides in powder samples using X-ray fluorescence analysis (Spectroscan Max-GV). Soil colors were described using the Munsell-System (Munsell soil color charts, 1992).

The suitability characteristics of fallow soils were based on integral assessment of nutritive element content (required macroelements, trace elements and useful elements [40]). A useful index of potential soil fertility (FI) is the ratio of the base cation elements, calcium and magnesium, and total phosphorus to silicon [41]. We modified the eluviation's coefficient [42] and in Ke calculation we used the formula: $\mathrm{Ke}=\mathrm{Si} /(\mathrm{Ca}+\mathrm{Mg}+\mathrm{Mn}+\mathrm{K}+\mathrm{Na})$. Mobility factor was assessed using the formula: $\mathrm{Km}=\left(\mathrm{Na}_{2} \mathrm{O}+\mathrm{K}_{2} \mathrm{O}+\mathrm{MgO}+\mathrm{Zn}\right) / \mathrm{SiO}_{2}$. Shaw [43] proposed the coefficient of accumulation of trace elements $(\mathrm{Ka})$ so as to calculate the arithmetical mean of the relationship of trace elements in the soil (S) to the parent rock $(\mathrm{P})$. We used the modification of this coefficient $\left(\mathrm{K}_{\mathrm{S}}\right)$ as a geometrical mean value $\mathrm{S} / \mathrm{P}$ for the trace elements group ( $\mathrm{Ni}, \mathrm{Zn}, \mathrm{Mn}, \mathrm{Pb}, \mathrm{Cu}, \mathrm{Co}, \mathrm{Mg}, \mathrm{Cr}, \mathrm{Fe}, \mathrm{Sr}, \mathrm{Rb}, \mathrm{V}$ ). In the cluster analysis of soil data, we used Ward's method, in which clustering procedures are based on the criterion of squared Euclidean distance.

\section{Results}

Soils of the Herakleian Peninsula are distinguished by high contents of phosphorus and iron relative to other areas of ancient viticulture. The features of the parent rocks and the process of soil weathering in hot climates, such as that on the Herakleian Peninsula, lead to the enrichment of brown soils with iron oxides, which give red wines of an intense color [24], and a golden tone to some white wines [8]. 
Considering the fundamental differences in the geochemistry of parent rock and their soils, the most significant differences in the contents of macro and trace elements were defined for the areas of the Herakleian Peninsula and NW Crimea (Table 1), that could potentially affect the quality of wine produced in those regions. Table 1 does not include the chemical elements for which the contents were below the detection limit, nor does it include the elements with a low coefficient of variation (V $\leq 10 \%$ : Ti, Mn, $\mathrm{Co}, \mathrm{K}, \mathrm{Rb}, \mathrm{Na}$, As.

Table 1. Geochemical features in horizon A of post-antique long-fallow lands under vineyards of ancient time on the near $(\mathrm{CN})$ and distant $(\mathrm{OR}, \mathrm{MT}, \mathrm{K}-\mathrm{L}, \mathrm{OT})$ chora Chersonesos.

\begin{tabular}{|c|c|c|c|c|c|c|c|c|c|c|c|c|c|}
\hline \multirow{2}{*}{ Soils } & $\mathrm{Ca}$ & Al & $\mathrm{Fe}$ & Si & $\mathrm{Mg}$ & $\mathbf{P}$ & $\mathrm{Ni}$ & $\mathrm{Cu}$ & $\mathrm{Zn}$ & $\mathrm{Sr}$ & $\mathbf{P b}$ & $\mathrm{Cr}$ & V \\
\hline & \multicolumn{6}{|c|}{$\%$} & \multicolumn{7}{|c|}{$\mathrm{mg} \mathrm{kg}^{-1}$} \\
\hline OR & 17.7 & 4.4 & 1.5 & 7.10 & 0.7 & 4.0 & 35.2 & 27.5 & 69.3 & 259.5 & 13.3 & 75.1 & 59.6 \\
\hline MT & 22.5 & 3.8 & 1.2 & 5.32 & 0.9 & 4.5 & 24.9 & 12.4 & 93.3 & 280.3 & 10.0 & 65.8 & 49.1 \\
\hline $\mathrm{K}-\mathrm{L}$ & 18.4 & 4.1 & 1.4 & 6.31 & 1.2 & 0.1 & 31.9 & 15.4 & 66.3 & 284.9 & 18.9 & 74.4 & 60.1 \\
\hline OT & 20.1 & 3.9 & 1.3 & 4.53 & 1.0 & 1.0 & 31.0 & 11.9 & 63.5 & 241.7 & 13.9 & 75.1 & 53.6 \\
\hline $\mathrm{CN} 3$ & 16.6 & 4.5 & 2.3 & 15.0 & 2.8 & 0.1 & 56.4 & 46.2 & 115.1 & 355.1 & 23.5 & 64.4 & 66.5 \\
\hline $\mathrm{CN} 49$ & 17.7 & 5.5 & 2.5 & 15.3 & 3.1 & 6.2 & 56.3 & 54.3 & 86.2 & 170.7 & 7.2 & 63.2 & 67.3 \\
\hline $\mathrm{CN} 62$ & 8.1 & 5.1 & 2.9 & 20.9 & 1.6 & 6.7 & 59.1 & 36.8 & 81.6 & 91.7 & 45.3 & 72.9 & 83.1 \\
\hline CN 68 & 18.6 & 5.6 & 2.3 & 14.8 & 3.0 & 9.0 & 60.0 & 39.6 & 108.1 & 152.7 & $<Q L$ & 65.7 & 71.4 \\
\hline CN 130-1 & 18.9 & 9.9 & 2.8 & 10.2 & 1.2 & 0.04 & 53.1 & 50.0 & 92.0 & 137.5 & 22.2 & 81.0 & 64.9 \\
\hline CN 130-2 & 19.8 & 10.0 & 2.7 & 11.0 & 1.3 & 0.1 & 49.7 & 47.1 & 89.1 & 157.3 & 22.5 & 78.7 & 70.8 \\
\hline CN 387 & 2.9 & 5.7 & 4.1 & 24.1 & 0.9 & 0.04 & 68.1 & 51.6 & 83.6 & 77.6 & 44.9 & 103.1 & 104.5 \\
\hline CN 389 & 9.7 & 5.1 & 3.1 & 19.5 & 1.8 & 4.3 & 62.2 & 48.9 & 99.3 & 216.4 & $<Q L$ & 83.8 & 85.5 \\
\hline CN 391-1 & 18.3 & 8.4 & 2.0 & 11.2 & 1.1 & 0.1 & 43.1 & 50.0 & 81.8 & 63.3 & 16.1 & 69.6 & 50.5 \\
\hline CN 391-2 & 14.7 & 9.3 & 1.9 & 16.6 & 0.9 & 0.1 & 25.8 & 27.9 & 92.9 & 72.3 & 14.7 & 69.9 & 57.0 \\
\hline CN 395 & 7.5 & 9.5 & 2.9 & 14.7 & 0.5 & 0.1 & 45.8 & 48.5 & 110.4 & 47.0 & 26.7 & 74.3 & 78.5 \\
\hline
\end{tabular}

Based on Table 1 (concentration of the most informative six macroelements and seven trace elements), data cluster analysis (Figure 2) was performed, and the results showed that coastal (OT and K-L) and inland (OR and MT) areas of NW Crimea with certain differences still formed a common cluster (group III) and were significantly different from plots in the Herakleian Peninsula (groups I and II).

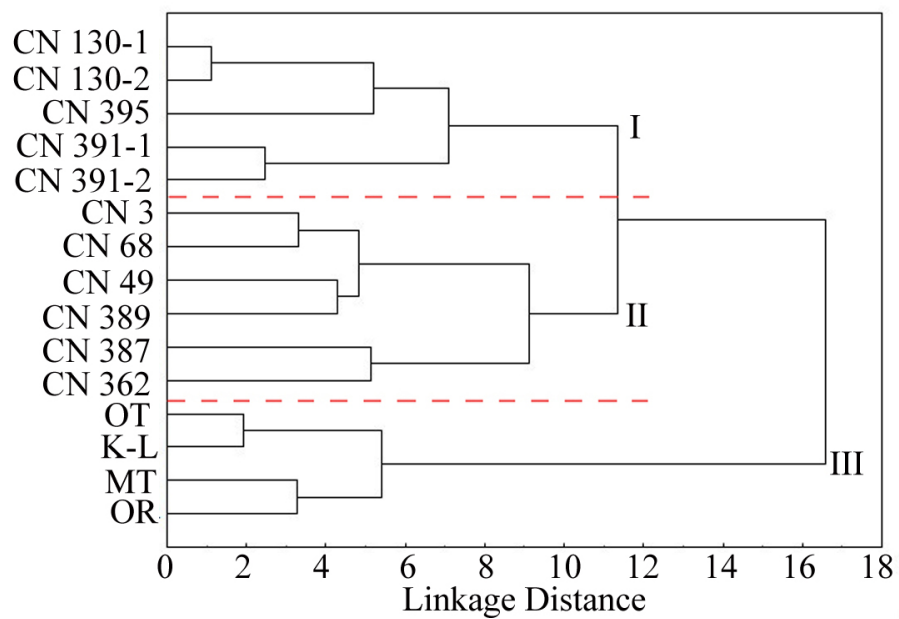

Figure 2. Dendrogram of cluster analysis of soils under vineyards of ancient times on in the Herakleian Peninsula and in selected areas of NW Crimea. I-III are groups of the vineyard soils.

The most informative geochemical indicators and average values by groups are presented in Table 2. 
Table 2. The main geochemical indicators and their average values for soil groups.

\begin{tabular}{cccccccc}
\hline Soils & $\mathbf{R b} / \mathbf{S r}$ & $\mathbf{K e}$ & $\mathbf{F I}$ & $\mathbf{K m}$ & $\mathbf{( F e}+\mathbf{A l}) /(\mathbf{C a}+\mathbf{N a}+\mathbf{M g})$ & $\mathbf{K a}$ & $\mathbf{K}_{\mathbf{S}}$ \\
\hline OR & 0.22 & 0.71 & 7.26 & 4.80 & 0.29 & 1.10 & 1.28 \\
MT & 0.18 & 0.42 & 11.24 & 8.60 & 0.19 & 0.92 & 1.12 \\
K-L & 0.17 & 0.57 & 1.68 & 5.30 & 0.24 & 1.26 & 1.68 \\
OT & 0.16 & 0.38 & 3.83 & 6.78 & 0.20 & 1.14 & 1.40 \\
average & 0.18 & 0.52 & 6.00 & 6.37 & 0.23 & 1.10 & 1.37 \\
CN 3 & 0.17 & 1.25 & 0.72 & 3.86 & 0.28 & 0.65 & 0.92 \\
CN 49 & 0.40 & 1.20 & 0.77 & 2.92 & 0.32 & 0.59 & 0.44 \\
CN 62 & 0.72 & 3.20 & 0.27 & 1.95 & 0.63 & 0.59 & 0.51 \\
CN 68 & 0.38 & 1.10 & 0.82 & 3.74 & 0.29 & 0.61 & 0.48 \\
CN 387 & 1.07 & 6.91 & 0.11 & 1.71 & 1.62 & 0.33 & 0.98 \\
CN 389 & 0.34 & 2.60 & 0.34 & 2.52 & 0.57 & 0.63 & 0.51 \\
average & 0.51 & 2.71 & 0.51 & 2.78 & 0.62 & 0.56 & 0.64 \\
CN 130-1 & 0.53 & 0.91 & 1.02 & 4.43 & 0.57 & 0.71 & 0.79 \\
CN 130-2 & 0.43 & 0.93 & 0.99 & 4.01 & 0.53 & 0.83 & 0.82 \\
CN 391-1 & 0.53 & 1.06 & 0.90 & 3.60 & 0.49 & 0.89 & 0.87 \\
CN 391-2 & 0.44 & 1.93 & 0.50 & 2.72 & 0.64 & 0.76 & 0.75 \\
CN 395 & 1.26 & 2.93 & 0.31 & 3.61 & 1.32 & 0.74 & 0.77 \\
average & 0.64 & 1.55 & 0.75 & 3.67 & 0.71 & 0.78 & 0.80 \\
\hline
\end{tabular}

Four geochemical indicators (FI, Km, Ka, $\mathrm{K}_{\mathrm{S}}$ ) of seven indicators (Table 2) showed higher values in group III (soils of NW Crimea), and the smallest values in group II, while group I occupies an intermediate position (soils in the area of Cape Fiolent). The eluviation's coefficient (Ke), which by its structure gives inverse values from the four indicators mentioned above, confirms this pattern. Thus, soils from areas of NW Crimea are characterized by a more active accumulation of trace elements, reduced migration mobility, and degree of weathering in the more alkaline conditions of soil solution.

The studied soils in relation to the parent rock (Table 3) are characterized by the greatest accumulation of phosphorus (average S/P ratio is 2.1), as well as $\mathrm{Si}, \mathrm{Zn}, \mathrm{K}, \mathrm{Cu}, \mathrm{Mn}$ (1.4-1.2). However, the soil of the two cuts (plot CN 130) is especially noticeably different from all other objects in the accumulation of $\mathrm{Si}, \mathrm{Fe}, \mathrm{Al}, \mathrm{K}, \mathrm{Ni}, \mathrm{Cu}, \mathrm{Co}, \mathrm{Mn}$. In addition to the plot of $\mathrm{CN}$ 130, a significant accumulation (above average) was noted for the objects OT, OR (trenching soils of NW Crimea), CN 395 and CN 391-1.

Table 3. The accumulation of the trace elements according to the ratio of concentrations in soil and parent rock $(\mathrm{S} / \mathrm{P})$.

\begin{tabular}{ccccccccccc}
\hline Soils & Al & Fe & Si & $\mathbf{P}$ & $\mathbf{K}$ & $\mathbf{N i}$ & $\mathbf{C u}$ & $\mathbf{Z n}$ & $\mathbf{M n}$ & $\mathbf{C o}$ \\
\hline OR & 0.58 & 0.80 & 0.50 & 5.35 & 1.01 & 1.16 & 1.77 & 1.10 & 1.07 & 1.50 \\
MT & 0.56 & 0.72 & 0.56 & 4.20 & 0.89 & 1.02 & 0.76 & 1.41 & 0.76 & 1.03 \\
K-L & 0.65 & 0.94 & 0.77 & 1.51 & 1.20 & 1.33 & 1.29 & 1.16 & 1.24 & 0.70 \\
OT & 0.48 & 0.81 & 0.39 & 7.61 & 0.89 & 1.13 & 0.78 & 1.08 & 0.89 & 1.30 \\
CN 3 & 0.42 & 0.52 & 0.82 & 1.08 & 1.13 & 0.75 & 0.73 & 1.24 & 0.60 & 0.10 \\
CN 49 & 0.78 & 0.98 & 1.14 & 1.19 & 1.29 & 1.23 & 1.43 & 1.47 & 1.65 & 0.10 \\
CN 62 & 0.66 & 1.15 & 1.65 & 1.08 & 0.94 & 1.08 & 0.69 & 1.25 & 1.38 & 0.10 \\
CN 68 & 0.52 & 0.53 & 0.80 & 1.22 & 1.03 & 0.80 & 0.63 & 1.16 & 0.67 & 0.10 \\
CN 130-1 & 1.60 & 1.96 & 3.66 & 0.96 & 1.84 & 1.98 & 1.63 & 1.30 & 1.70 & 2.69 \\
CN 130-2 & 1.48 & 1.67 & 3.53 & 1.03 & 1.54 & 1.26 & 1.57 & 1.26 & 1.58 & 2.53 \\
CN 387 & 0.53 & 0.93 & 1.31 & 0.82 & 0.98 & 0.91 & 0.82 & 0.90 & 1.05 & 0.21 \\
CN 389 & 0.47 & 0.73 & 1.06 & 0.95 & 1.05 & 0.83 & 0.78 & 1.07 & 0.82 & 0.10 \\
CN 391-1 & 0.86 & 0.83 & 1.30 & 1.39 & 1.19 & 1.13 & 1.88 & 1.10 & 1.57 & 1.78 \\
CN 391-2 & 0.95 & 0.79 & 1.93 & 1.45 & 1.29 & 0.68 & 1.05 & 1.25 & 1.50 & 0.87 \\
CN 395 & 0.97 & 1.24 & 1.71 & 1.40 & 1.58 & 1.21 & 1.82 & 1.48 & 1.21 & 1.40 \\
\hline
\end{tabular}


For a more detailed analysis, we selected the most contrasting objects from the plots in the Herakleian Peninsula: calcareous rendzina soil (CN 3) and cinnamonic soil at Cape Fiolent (CN 387), which primarily differ sharply in the content of $\mathrm{CaCO}_{3}: 7.3 \%$ (CN 3) and 59.5\% (CN 387) (Table 4).

Table 4. Agrochemical properties of soils in deposits on the antique vineyards of the near $(\mathrm{CN})$ and distant districts of Chersonesos.

\begin{tabular}{|c|c|c|c|c|c|c|c|c|c|c|}
\hline \multirow{3}{*}{ Soils } & \multirow{3}{*}{ Color (Dry) } & \multirow{3}{*}{ Layer, cm } & \multirow{3}{*}{$\mathrm{pH}\left(\mathrm{H}_{2} \mathrm{O}\right)$} & \multirow{3}{*}{ Corg } & \multirow{3}{*}{$\begin{array}{c}\mathrm{CO}_{2} \text { Carbonates } \\
\%\end{array}$} & \multicolumn{2}{|c|}{ Available } & \multirow{2}{*}{\multicolumn{3}{|c|}{$\mathrm{CEC}, \mathrm{cmol} \mathrm{kg}^{-1}$}} \\
\hline & & & & & & $\mathbf{P}$ & $\mathbf{K}$ & & & \\
\hline & & & & & & \multicolumn{2}{|c|}{$\mathrm{mg} \mathrm{kg}^{-1}$} & $\mathrm{Mg}^{2+}$ & $\mathrm{Ca}^{2+}$ & $\mathrm{Na}^{+}$ \\
\hline OT & 10YR 6/3 & $5-21$ & 8.5 & 2.4 & 25.1 & 1.5 & 366.6 & 4.4 & 19.8 & 1.6 \\
\hline $\mathrm{K}-\mathrm{L}$ & 10YR 6/3 & $0-24$ & 8.3 & 2.0 & 18.9 & 0.2 & 128.0 & 7.7 & 34.1 & 2.4 \\
\hline MT & 10 YR $6 / 3$ & $0-20$ & 8.8 & 1.9 & 26.8 & 10.4 & 290.1 & 2.1 & 18.6 & 0.2 \\
\hline OR & 10YR $5 / 3$ & $0-21$ & 8.1 & 1.5 & 19.5 & 9.2 & 221.5 & 2.2 & 27.5 & 0.1 \\
\hline $\mathrm{CN} 3$ & 10YR 5/6 & $0-16$ & 7.9 & 2.6 & 23.3 & 12.2 & 12.0 & 2.4 & 16.8 & 0.1 \\
\hline CN 387 & 7.5 YR $3 / 4$ & $0-16$ & 7.8 & 3.2 & 3.2 & 8.5 & 8.0 & 1.6 & 38.8 & 0.1 \\
\hline CN 49 & 10YR 6/4 & $0-16$ & 7.9 & 3.0 & 21.2 & 14.2 & 11.0 & 1.8 & 21.6 & 0.1 \\
\hline CN 389 & 10YR 5/4 & $4-16$ & 7.8 & 2.5 & 10.1 & 9.8 & 13.0 & 1.6 & 29.2 & 0.1 \\
\hline CN 62 & 5YR 5/6 & $0-16$ & 7.9 & 2.5 & 21.7 & 15.4 & 10.0 & 1.6 & 17.0 & 0.1 \\
\hline CN 68 & 7.5YR 5/7 & $0-16$ & 7.9 & 3.1 & 20.6 & 20.6 & 15.0 & 1.6 & 19.6 & 0.1 \\
\hline
\end{tabular}

Soils of the NW Crimea are carbonate Chernozem and rendzina soils, the last are sometimes met in the Herakleian Peninsula. Such soils have high carbonate content, moderate and strong alkaline reaction of soil solution, deficiency of available $\mathrm{P}_{2} \mathrm{O}_{5}$ (see Table 4). The soils of NW Crimea, when compared to the plots in the Herakleian Peninsula, have a significant participation of magnesium and sodium in the cation exchange capacity, because of which the soils are less structural. The resulting regression equation showed that with increasing carbonate content $\left(\mathrm{CO}_{2}\right)$ from $3 \%$ to $27 \%$, the CEC value was halved. Among the studied soils, only two cinnamonic soils near Cape Fiolent (CN 387 and CN 389) had a higher soil absorption capacity.

\section{Discussion}

A comparison of the soils under the vineyards of an aggregate of 20 chemical elements showed a fundamental difference between the geochemical environment in NW Crimea, which is in a natural state $[37,38]$; this was a result of trenching soil that inherited (obtained) a great influence of eluvium of dense carbonate rocks, and soils in the Herakleian Peninsula were due to a large area where there were spatial differences in the soil features. This primarily relates to the geochemical specificity of soils in the area of Cape Fiolent in comparison with the other areas of chora Chersonesos.

The analysis of differences among the four objects in NW Crimea and key objects in SW Crimea (CN 3 and CN 387), according to the values of the factors Shaw (Ka) and $K_{S}$, showed the highest concentration of 12 trace elements in the soil CN 387 and the smallest in the soil CN 3, respectively (Table 2). This showed that in the Herakleian Peninsula, there are spatial differences in the geochemical composition of soils under ancient vineyards. Carbonate rendzina soil (CN 3), in contrast to the other soils in the plots in the Herakleian Peninsula, was the closest to the objects in NW Crimea, and they differed only by a higher Ke value and smaller values of the other factors FI.

In NW Crimea, the same characteristics of the accumulation of trace elements are marked for OT, $\mathrm{K}-\mathrm{L}, \mathrm{OR}$, and the most depleted soil is under the vineyard MT. This is because, compared to three other objects in NW Crimea, this object has less value S/P in 9 elements of 20, including essential elements- $\mathrm{Mn}, \mathrm{Fe}, \mathrm{Ni}, \mathrm{Cu}$, and $\mathrm{K}$ analyses of the accumulation of the trace elements in four objects in NW Crimea showed that they were united by the accumulation of 5 to 9 trace elements in the soil, but the most frequent elements were included in the array: $(\mathrm{Zn}, \mathrm{Ni}, \mathrm{V})>\mathrm{Pb}>\mathrm{Co}>\mathrm{Rb}>\mathrm{Cr}>\mathrm{Cu}>\mathrm{Mn}$.

Geochemical specifics of the soil in the plot CN 387 were determined by higher values $(>1)$ of the ratio of the elemental concentrations to the average content in the soils of NW Crimea, and the plot CN 
3 demonstrates the array $(\mathrm{Pb}, \mathrm{Fe})>\mathrm{Cu}>\mathrm{Ni}>\mathrm{V}>(\mathrm{As}, \mathrm{Rb})>\mathrm{MnO}>\mathrm{Cr}$, and also lower concentrations $\mathrm{Mg}, \mathrm{Co}, \mathrm{Sr}$.

Based on the studied Crimean soils of ancient land use, we can determine the overall number of accumulated chemical elements in the soil relative to the parent rock $(\mathrm{S} / \mathrm{P}): \mathrm{P}>\mathrm{Zn}>(\mathrm{K}, \mathrm{Mn})>(\mathrm{Co}, \mathrm{Si})$ $>\mathrm{Cu}>\mathrm{Ni}>\mathrm{Fe}>\mathrm{Al}$. Three groups of objects that are reflected on the dendrogram vary in the number of chemical elements that accumulated in the soil relative to the parent rock: in I, III, and II groups-10, 7 , and 5, respectively. The descending arrays of the accumulated elements for the three groups reflect their differences:

I group: $\mathrm{Co}>\mathrm{SiO}_{2}>\mathrm{Cu}>\mathrm{MnO}>\mathrm{K}_{2} \mathrm{O}>\left(\mathrm{Fe}_{2} \mathrm{O}_{3}, \mathrm{Ni}, \mathrm{Zn}\right)>\left(\mathrm{Al}_{2} \mathrm{O}_{3}, \mathrm{P}_{2} \mathrm{O}_{5}\right)$;

II group: $\mathrm{Zn}>\left(\mathrm{SiO}_{2}, \mathrm{P}_{2} \mathrm{O}_{5}, \mathrm{~K}_{2} \mathrm{O}\right)>\mathrm{MnO}$;

III group: $\mathrm{P}_{2} \mathrm{O}_{5}>\mathrm{Cu}>\mathrm{Co}>(\mathrm{Ni}, \mathrm{Zn})>\left(\mathrm{MnO}, \mathrm{K}_{2} \mathrm{O}\right)$.

The elements that most distinguish the groups from one another are $\mathrm{Fe}, \mathrm{Al}, \mathrm{Ni}, \mathrm{Cu}, \mathrm{Si}, \mathrm{Co}$. In all groups there is accumulation of $\mathrm{P}, \mathrm{K}, \mathrm{Mn}, \mathrm{Zn}$.

Geochemical correlations and factors may determine the results of processes that are linked with parent rock weathering and pedogenesis. In our study, the most informative factors were $\mathrm{FI}, \mathrm{Ke}, \mathrm{Km}$ (Table 2). The highest values of FI are noted in soils of NW Crimea due to the higher calcium content, as well as phosphorus, but not in all cases. The soils of this region have on average a greater CEC value (1.2 times) than the soils of the Herakleian Peninsula, which is associated with a greater participation of absorbed magnesium and sodium in the composition of the CEC.

The soil in the plots CN 387, such as most of the other objects in the Herakleian Peninsula, differed from the four objects in NW Crimea; specifically, had higher values of Ke and ratios $\mathrm{Rb} / \mathrm{Sr},(\mathrm{Fe}+\mathrm{Al}) /(\mathrm{Ca}+\mathrm{Mg}+\mathrm{Na})$. These values characterize the deeper processes of weathering and the removal of mobile elements that were related to longer farming duration near Chersonesos; additionally, these values reflect the higher intensity of geochemical transformations of rock and soils under the former and modern climatic conditions.

The geochemical characteristics of the fallow soils under the ancient vineyards at the near (cinnamonic soils) and distant (rendzina soils) chora of Chersonesos were largely determined by the differences in the contents of six macro-elements $(\mathrm{Ca}, \mathrm{Al}, \mathrm{Fe}, \mathrm{Si}, \mathrm{Mg}, \mathrm{P})$ and seven trace elements $(\mathrm{Ni}, \mathrm{Cu}, \mathrm{Zn}, \mathrm{Sr}, \mathrm{Pb}, \mathrm{Cr}, \mathrm{V}$ ). If the cinnamonic soils of Chersonesos mostly accumulated $\mathrm{Si}, \mathrm{K}, \mathrm{Fe}, \mathrm{Al}$, $\mathrm{P}_{2} \mathrm{O}_{5}$, the grape soils of distant chora differed by the predominance of $\mathrm{V}, \mathrm{Pb}, \mathrm{Rb}, \mathrm{Cr}$.

\section{Conclusions}

Cinnamonic soils near Chersonesos formed in a hotter climate than those in other regions of ancient viticulture; thus, the processes of soil weathering were more intense near Chersonesos, particularly in terms of the changes in the geochemistry of soils and rock. For example, due to the accumulation of iron oxides obtained from such soils, red wines have gained intense color. Our hypothesis that the cause of the minor (not export) role of local viticulture and wine consumption in the development of distant chora of the Chersonesos in NW Crimea from between the 4th and 3rd centuries BC and for 50-60 years was associated with the biogeochemical specificity of the soils and parent rock was confirmed. This conclusion is consistent with the differences in the roles of viticulture and winemaking in NW and SW Crimea, which have been noted by historians. If Chersonesos, in the second half of the 4 th century $B C$ to the first third of the 3rd century BC, produced wine for export at an annual rate of 700-800 dal, the area would have supplied wine to the ancient centers of the South Black Sea region, the Mediterranean, and also to the distant chora in the NW Crimea [29]; thus, viticulture in NW Crimea met the domestic needs for 40 major and smaller ancient settlements in the area. The geochemical differences of the root layer of a grape plant and the significant contribution of different types of local climate (seaside steppe and the Sub-Mediterranean) define the difference in the quality of wines produced in two regions of western Crimea. Furthermore, this difference is reflected in the differences in modern viticulture in these areas based on the "terroir" concept. 
Author Contributions: F.L. methodology, data curation, writing—original draft; E.Z. resources, investigation; M.R. analysis, validation, visualization.

Funding: The work was done in the framework of the implementation of the base part of the state assignment of the Ministry of Education and Science of the Russian Federation for the Belgorod State National Research University on 2017-2019 years (project No. 5.4711.2017/6.7).

Acknowledgments: We would like to acknowledge the kind assistance for advisory support on archaeology issues T.N. Smekalova. The manuscript was greatly improved by comments from three anonymous reviewers and is greatly appreciated. We thank April Troester for correcting the English language.

Conflicts of Interest: The authors declare no conflicts of interest. The funding sponsors did not take part in the design of the study; in the collection, analyses, or interpretation of data; in the writing of the manuscript; or in the decision to publish the results.

\section{References}

1. Riccioli, F.; El Asmar, T.; El Asmar, J.-P.; Fratini, R. Use of cellular automata in the study of variables involved in land use changes: An application in the wine production sector. Environ. Monit. Assess. 2013, 185, 5361-5374. [CrossRef] [PubMed]

2. Tana, C.M.; Marginean, M.C.; Tita, O. Characterization vineyard soil agrochemical Tarnave. In Proceedings of the 13th International Multidisciplinary Scientific GeoConference \& EXPO SGEM, Albena, Bulgaria, 16-22 June 2013; pp. 521-526. [CrossRef]

3. Marginean, M.C.; Tana, C.M.; Tiţa, O. Soil characteristics from Tarnave vineyard. In Proceedings of the 13th International Multidisciplinary Scientific GeoConference \& EXPO SGEM, Albena, Bulgaria, 16-22 June 2013; pp. 663-668. [CrossRef]

4. Ash, C.; Vacek, O.; Jakšík, O.; Tejnecký, V.; Drábek, O. Elevated soil copper content in a Bohemian vineyard as a result of fungicide application. Soil Water Res. 2012, 7, 151-158. [CrossRef]

5. Bažon, I.; Bakić, H.; Romić, M. Soil geochemistry as a component of terroir of the wine-growing station Jazbina, Zagreb. Agric. Conspectus Sci. 2013, 78, 95-106.

6. Huzum, R.; Sirbu-Radasanu, D.S.; Iftode, S.P.; Buzgar, N.; Iancu, G.O. Soil surface geochemistry for environment monitoring in vineyard soil of HuŞi area, Romania. In Proceedings of the International Multidisciplinary Scientific GeoConference \& EXPO SGEM, Albena, Bulgaria, 18-24 June 2015; Volume 2, pp. 295-302. [CrossRef]

7. Sandor, J.A.; Homburg, J.A. Anthropogenic soil change in ancient and traditional agricultural fields in arid to semiarid regions of the Americas. J. Ethnobiol. 2017, 37, 196-217. [CrossRef]

8. Negrul, A.M.; Krylatov, A.K. Selection of Lands and Varieties for Vineyards; Selkhozizdat: Moscow, Russia, 1964.

9. Preston, W.; do Nascimento, C.W.A.; da Silva, Y.J.A.B.; Silva, D.J.; Ferreira, H.A. Soil fertility changes in vineyards of a semiarid region in Brazil. J. Soil Sci. Plant Nutr. 2017, 17, 672-685. [CrossRef]

10. Protano, G.; Rossi, S. Relationship between soil geochemistry and grape composition in Tuscany (Italy). J. Plant Nutr. Soil Sci. 2014, 177, 500-508. [CrossRef]

11. Jones, G.V.; Snead, N.; Nelson, P. Geology and wine 8. Modeling viticultural landscapes: A GIS analysis of the terroir potential in the Umpqua Valley of Oregon. Geosci. Can. 2004, 31, 167-178.

12. Van Leeuwen, C.; Seguin, G. The concept of terroir in viticulture. J. Wine Res. 2006, 17, 1-10. [CrossRef]

13. Bodin, F.; Morlat, R. Characterization of viticultural terroirs using a simple field model based on soil depth I. Validation of the water supply regime, phenology and vine vigour, in the Anjou vineyard (France). Plant Soil 2006, 281, 37-54. [CrossRef]

14. Kiriliuk, V.P. Microelements in the Components of the Biosphere of Moldova; Pontos: Chisinau, Moldova, 2006.

15. Schwab, A.P.; Zhu, D.S.; Banks, M.K. Influence of organic acids on the transport of heavy metals in soil. Chemosphere 2008, 72, 986-994. [CrossRef] [PubMed]

16. Navarro, F.J.G.; Ortiz-Villajos, J.A.A.; Jiménez, C.J.S.; Ballesta, R.J. Red soil geochemistry in a semiarid Mediterranean environment and its suitability for vineyards. Environ. Geochem. Health 2011, 33, $279-289$. [CrossRef] [PubMed]

17. Amorós, J.A.; Pérez-de-los Reyes, C.; García Navarro, F.J.; Bravo, S.; Chacón, J.L.; Martínez, J.; Jiménez Ballesta, R. Bioaccumulation of mineral elements in grapevine varieties cultivated in "La Mancha". J. Plant Nutr. Soil Sci. 2013, 176, 843-850. [CrossRef] 
18. Kalinitchenko, V.P. Status of the Earth's geochemical cycle in the standard technologies and waste recycling, and the possibilities of its correction by Biogeosystem Technique method (problem-analytical review). Biogeosyst. Tech. 2016, 8, 115-144. [CrossRef]

19. Batukaev, A.-M.A.; Endovitsky, A.P.; Andreev, A.G.; Kalinichenko, V.P.; Minkina, T.M.; Dikaev, Z.S.; Mandzhieva, S.S.; Sushkova, S.N. Ion association in water solution of soil and vadose zone of chestnut saline solonetz as a driver of terrestrial carbon sink. Solid Earth 2016, 7, 415-423. [CrossRef]

20. Prikhodko, V.E.; Manakhov, D.V. Soil processes at different structural levels of organization and diagnosis of their changes under irrigation. Moscow Univ. Soil Sci. Bull. 2009, 65, 52-60. [CrossRef]

21. Prikhod'ko, V.E.; Ivanov, I.V.; Manakhov, D.V.; Gerasimenko, N.P.; Inubushi, K.; Kawahigashi, M.; Nagano, K.; Sugihara, S. Soils, vegetation, and climate of the southern Transural region in the Middle Bronze Age (by the example of the Arkaim fortress). Eur. Soil Sci. 2013, 46, 925-934. [CrossRef]

22. Bu, K.; Freile, D.; Cizdziel, J.V.; Richards, J.; Sidhu, V.; Duzgoren-Aydin, N.S. Geochemical characteristics of soils on Ellis Island, New York-New Jersey, sixty years after the abandonment of the hospital complex. Geosciences 2018, 8, 13. [CrossRef]

23. Pardini, G.; Gispert, M.; Dunjó, G. Distribution patterns of soil properties in a rural Mediterranean area in north-eastern Spain. Mountain Res. Dev. 2004, 24, 44-51. [CrossRef]

24. Akimtsev, V.V. Soil and quality of wines. Pochvovedenie 1950, 5, $296-302$.

25. Cordova, C.E.; Lehman, P.H. Archaeopalynology of synanthropic vegetation in the chora of Chersonesos, Crimea, Ukraine. J. Archaeol. Sci. 2003, 30, 1483-1501. [CrossRef]

26. Kashirskaya, N.N.; Khomutova, T.E.; Kuznetsova, T.V.; Shishlina, N.I.; Borisov, A.V. Dynamics of Chemical and Microbiological Soil Properties in the Desert-Steppe Zone of the Southeast Russian Plain during the Second Part of the Holocene (4000 BC-XIII century AC). Arid Ecosyst. 2018, 8, 38-46. [CrossRef]

27. Kerzhentsev, A.S. New Book on the Structural-Functional Role of Soils in the Biosphere. Eur. Soil Sci. 2006, 39, 95-102. [CrossRef]

28. Prikhod'ko, V.E. Changes in soil properties at different levels of soil structural arrangement under the impact of irrigation. Eur. Soil Sci. 2008, 41, 114-124. [CrossRef]

29. Vinokurov, N.I. Viticulture and wine production in the antique states of the Northern Black Sea area. Bosporos Stud. 2007, 3, 22-39.

30. Smekalova, T.N.; Bevan, B.W.; Chudin, A.V.; Garipov, A.S. The discovery of an ancient Greek vineyard. Archaeol. Prospect. 2016, 23, 15-23. [CrossRef]

31. Ivanov, I.V.; Lisetskiy, F.N. Correlation of soil formation rhythms with periodicity of solar activity over the last 5000 years. Trans. Russ. Acad. Sci. Earth Sci. Sect. 1996, 340, 189-194.

32. Saprykin, S.J. Ancient Farms and Land Plots on the Khora of Khersonesos Taurike; Brill Academic Publishers: Amsterdam, The Netherlands, 1994.

33. Lisetskii, F.N.; Goleusov, P.V.; Chepelev, O.A. The development of Chernozems on the Dniester-Prut interfluve in the Holocene. Eur. Soil Sci. 2013, 46, 491-504. [CrossRef]

34. Valkó, O.; Deák, B.; Török, P.; Kelemen, A.; Miglécz, T.; Tóth, K.; Tóthmérész, B. Abandonment of croplands: Problem or chance for grassland restoration? Case studies from Hungary. Ecosyst. Health Sustain. 2016, 2, e01208. [CrossRef]

35. Bagrova, L.A.; Bokov, V.A.; Bagrov, N.V. Geografija Kryma; Lybid: Kyiv, Ukraine, 2001.

36. Korsakova, S. Impact of climate change on the grape productivity in the Southern coast of the Crimea. In Challenges and Opportunities in Agrometeorology; Attri, S.D., Rathore, L.S., Sivakumar, M.V.K., Dash, S.K., Eds.; Springer: Berlin/Heidelberg, Germany, 2011; pp. 385-396.

37. Lisetskii, F.N.; Stolba, V.F.; Pichura, V.I. Late-Holocene palaeoenvironments of Southern Crimea: Soils, soil-climate relationship and human impact. Holocene 2017, 27, 1859-1875. [CrossRef]

38. Lisetskii, F.; Stolba, V.; Ergina, E.; Rodionova, M.; Terekhin, E. Post-agrogenic evolution of soils in ancient Greek land use areas in the Herakleian Peninsula, South-West Crimea. Holocene 2013, 4, 504-514. [CrossRef]

39. Golyeva, A.; Khokhlova, O.; Lebedeva, M.; Shcherbakov, N.; Shuteleva, I. Micromorphological and chemical features of soils as evidence of bronze age ancient anthropogenic impact (Late Bronze Age Muradymovo settlement, Ural region, Russia). Geosciences 2018, 8, 313. [CrossRef]

40. Marken, B. Instrumental Element and Multi-Element Analysis of Plant Samples; John Wiley and Sons: New York, NY, USA, 1996. 
41. Taylor, G.; Pain, C.F.; Ryan, P.J. Geology, geomorphology and regolith. In Guidelines for Surveying Soil and Land Resources; McKenzie, N.J., Grundy, M.J., Webster, R., Ringrose-Voase, A.J., Eds.; Csiro: Melbourne, Australia, 2008; pp. 45-60.

42. Liu, G.; Li, L.; Wu, L.; Wang, G.; Zhou, Z.; Du, S. Determination of soil loss tolerance of an Entisol in Southwest China. Soil Sci. Soc. Am. J. 2009, 73, 412-417. [CrossRef]

43. Shaw, D.M. Interprétation Geochimique des Éléments en Traces Dans les Roches Cristallines; Masson: Paris, France, 1964. 